\title{
Characterization of Colletotrichum Isolates from Tamarillo, Passiflora, and Mango in Colombia and Identification of a Unique Species from the Genus
}

\author{
Lucia Afanador-Kafuri, Dror Minz, Marcel Maymon, and Stanley Freeman
}

First author: Departamento de Ciencias Agronómicas, Universidad Nacional de Colombia, Medellín, Colombia; second author: Institute of Soil, Water, and Environmental Sciences, ARO, The Volcani Center, P.O. Box 6, Bet Dagan 50250; and third and fourth authors: Department of Plant Pathology, ARO, The Volcani Center, P.O. Box 6, Bet Dagan 50250, Israel.

Accepted for publication 23 November 2002.

\begin{abstract}
Afanador-Kafuri, L., Minz, D., Maymon, M., and Freeman, S. 2003. Characterization of Colletotrichum isolates from tamarillo, passiflora, and mango in Colombia and identification of a unique species from the genus. Phytopathology 93:579-587.

This study was conducted to identify the species of Colletotrichum infecting tamarillo, mango, and passiflora in Colombia and to assess whether cross-infection between host species is occurring. Isolates of Colletotrichum spp. from tamarillo $(n=54)$, passiflora $(n=26)$, and mango $(n=15)$ were characterized by various molecular methods and by morphological criteria. Morphological characterization grouped the tamarillo isolates as C. acutatum and the passiflora and mango isolates as C. gloeosporioides. Species-specific primer analysis was reliable and confirmed grouping of the tamarillo isolates (besides Tom-6) as C. acutatum and the mango isolates (besides Man-76) as C. gloeosporioides. However, DNA of the passiflora isolates was not amplified by either $C$. acutatum- or $C$. gloeosporioides-specific primers, but reacted with a new

positively with the Col1 primer. All the isolates reacting with the $C$. acutatum- and C. gloeosporioides-specific primers failed to react with primer Col1. Isolate Pass-35 from passiflora did not react with any of the taxon-specific primers. Arbitrarily primed polymerase chain reaction (apPCR), random amplified polymerase DNA (RAPD)-PCR, and A+T-rich DNA analyses delineated representative isolates into subgroups within the designated species. Molecular analyses indicated that the $C$. acutatum tamarillo isolates were uniform or clonal, whereas the $C$. gloeosporioides mango isolates and Colletotrichum passiflora isolates were heterogeneous. Likewise, sequence analysis of the complete ITS (ITS1-5.8SITS2) region identified certain isolates to their respective species: tamarillo isolates as $C$. acutatum; mango isolates as C. gloeosporioides; passiflora, Tom-6, and Man-76 isolates as a Colletotrichum sp. as yet undefined; and the Pass-35 isolate as an additional undefined Colletotrichum sp. Molecular analyses of the population of Colletotrichum isolates from passiflora, Tom-6 from tamarillo, and Man-76 from mango indicate that this population may not be host specific.
\end{abstract} primer, Col1, designed according to the internal transcribed spacer (ITS) 1 region of these isolates. Isolates Tom- 6 and Man-76 also reacted
Additional keywords: Glomerella cingulata, phylogeny, rDNA.
Colombian tamarillo (Solanum betacea cav. Sendt) cultivation comprises more than 4,500 ha, with the largest plantation areas located in the Antioquia, Boyaca, Caldas, Cauca, and Cundinamarca states (4). Increased planting of tamarillo in Colombia has caused the spread and development of diseases such as anthracnose. Anthracnose has become a major threat to the tamarillo industry, not only causing severe damage to fruit but also affecting flowers and leaves. Symptoms include depressed black lesions on fruit accompanied by erupting pink spore masses in lesions, and round to irregular necrotic lesions on leaves with depressed lesions on main veins (4). Yield losses due to anthracnose of tamarillo can be greater than $50 \%$.

The causal agent of anthracnose in tamarillo and other tropical fruit in Colombia, such as mango, custard apple, avocado, passiflora species, solanaceous species, citrus, and guava, has been referred to as Colletotrichum gloeosporioides (Penz.) Penz. \& Sacc. in Penz. (7). C. gloeosporioides strains obtained from these hosts have shown a wide range of variability in morphology and pathogenicity and, in several cases, have been referred to as a collective species (21). Characterization and taxonomic determination of Colletotrichum spp. has relied mainly on morphology and host range criteria. High variability of Colletotrichum spp.

Corresponding author: S. Freeman; E-mail address: freeman@volcani.agri.gov.il

Publication no. P-2003-0221-01R

(c) 2003 The American Phytopathological Society under culture conditions and the plasticity of this fungus for host preferences have made these two criteria unreliable for identifying isolates to species $(2,5,11)$. Colletotrichum spp. have a wide host range, with cases of multiple pathogens on a single host as well as single species on diverse hosts (12). Cross-infection potential among different species of Colletotrichum has been well documented $(3,5,17)$. The importance for species differentiation is critical for control purposes. For example, in mixed populations of Colletotrichum spp., such as C. acutatum and C. gloeosporioides, sensitivity of one species to a certain fungicide (e.g., benomyl) as opposed to the other may cause a shift in population structure $(2,5,12,22)$.

Molecular tools have been widely implemented for more accurate differentiation between Colletotrichum spp. Species-specific polymerase chain reaction (PCR) primers, random amplified polymorphic DNA (RAPD), arbitrarily primed (ap)-PCR (16), A+Trich analyses (15), and sequence analyses of the internal transcribed spacer (ITS) regions of ribosomal DNA (rDNA) (28) all have been used to reliably determine intra- and interspecific genetic diversity in Colletotrichum spp.

This study was undertaken to evaluate the composition of $\mathrm{Col}$ letotrichum spp. infecting tamarillo, mango, and passiflora in Colombia and to determine whether or not cross-infection between host species was occurring. We used a molecular approach for identifying the species infecting the various crops, because morphological criteria were not reliable enough for this purpose. Species-specific primer, ap-PCR, RAPD-PCR, A+T-rich DNA, 
and sequence analyses of the ITS regions of rDNA were performed to identify the Colletotrichum spp. responsible for anthracnose of tamarillo, mango, and passiflora and to assess the genetic diversity within the Colletotrichum populations from each host.

\section{MATERIALS AND METHODS}

Fungal cultures and growth conditions. Colletotrichum strains associated with anthracnose disease symptoms on tamarillo, mango, and passiflora were isolated over the period of 1998 to 2000 from several regions of Colombia (Table 1). All Colletotrichum isolates were grown on potato dextrose agar (Difco Laboratories, Detroit) at $24^{\circ} \mathrm{C}$ and single-spore isolates were prepared from each culture for morphological and molecular characterization. Isolates from tamarillo, passiflora, and mango, that were not clearly defined by molecular methods, were sent to P. F. Cannon of CABI Bioscience (Egham, Surrey, UK) for morphological identification and the cultures were deposited in the CABI culture collection. The tamarillo (Tom-6; IMI 386922), passiflora (Pass-35; IMI 386920), and mango (Man-76; IMI 386921) isolates were identified within the C. gloeosporioides species aggregate, with several unusual features (P. F. Cannon, personal communication), and are described in Table 2. In addition, isolates Tom-9 from tamarillo, Pass-62 from passiflora, and Man-75 from mango also were thoroughly characterized morphologically by us in this study. For determination of size, 40 conidia of each isolate (Tom-6, Tom-9, Pass-35, Pass-62, Man-75, and Man-76) were selected per microscopic field on PDA medium, and their average measurements were calculated (Table 2). Representative Colletotrichum cultures used in this study for molecular analyses included isolate AVO-37-4B of C. gloeosporioides from avocado (13) and isolate TUT-5954 of $C$. acutatum from strawberry (10).

Isolation and purification of fungal DNA. All Colletotrichum isolates (54 from tamarillo, 26 from passiflora, and 15 from mango) were grown in $100 \mathrm{ml}$ of potato dextrose broth (PDB) at $24^{\circ} \mathrm{C}$ for 7 days. Thereafter, the mycelium was collected by vacuum filtration and lyophilized until dry. DNA was extracted and purified as previously described (15). The DNA was dissolved in $0.5 \mathrm{ml}$ of Tris-EDTA buffer (10 mM Tris-HCl, $1 \mathrm{mM}$ EDTA; $\mathrm{pH}$ 8.0) to an approximate concentration of 200 to $500 \mu \mathrm{g} / \mathrm{ml}$ and diluted to a final concentration of 10 to $100 \mathrm{ng} / \mu \mathrm{l}$ for PCR reactions.

PCR amplification. For ap-PCR, primers were derived from microsatellite or repeat sequences as follows: CAGCAGCAGC-

TABLE 1. Sources of Colletotrichum spp. isolates used in this study

\begin{tabular}{|c|c|c|c|c|}
\hline Isolate $^{\mathrm{a}}$ & Host species & Location $^{\mathrm{b}}$ & Tissue & Collection date \\
\hline Tom-2 & Tamarillo & Entrerios, Antioquia & Fruit & 1998 \\
\hline Tom-3 & Tamarillo & Entrerios, Antioquia & Fruit & 1998 \\
\hline Tom-4 & Tamarillo & Santa Rosa, Antioquia & Fruit & 1998 \\
\hline Tom-5 & Tamarillo & Santa Rosa, Antioquia & Flower & 1998 \\
\hline Tom-6 & Tamarillo & San Pedro, Antioquia & Leaf & 1998 \\
\hline Tom-7 & Tamarillo & Entrerios, Antioquia & Flower & 1998 \\
\hline Tom-8 & Tamarillo & Rionegro, Antioquia & Leaf & 1998 \\
\hline Tom-9 & Tamarillo & Rionegro, Antioquia & Fruit & 1998 \\
\hline Tom-10 & Tamarillo & Rionegro, Antioquia & Fruit & 1998 \\
\hline Tom-11 & Tamarillo & Santa Rosa, Antioquia & Fruit & 1998 \\
\hline Tom-12 & Tamarillo & Santa Rosa, Antioquia & Flower & 1998 \\
\hline Tom-13 & Tamarillo & Don Matias, Antioquia & Fruit & 1998 \\
\hline Tom-14 & Tamarillo & Santa Rosa, Antioquia & Flower & 1998 \\
\hline Tom-15 & Tamarillo & Don Matias, Antioquia & Fruit & 1998 \\
\hline Tom-16 & Tamarillo & Guarne, Antioquia & Leaf & 1998 \\
\hline Tom-17 & Tamarillo & San Pedro, Antioquia & Fruit & 1998 \\
\hline Tom-18 & Tamarillo & Guarne, Antioquia & Flower & 1998 \\
\hline Tom-21 & Tamarillo & San Vicente, Antioquia & Flower & 1998 \\
\hline Tom-22 & Tamarillo & La Unión, Antioquia & Flower & 1998 \\
\hline Tom-23 & Tamarillo & Guarne, Antioquia & Flower & 1998 \\
\hline Tom-24 & Tamarillo & La Unión, Antioquia & Fruit & 1998 \\
\hline Tom-25 & Tamarillo & La Unión, Antioquia & Leaf & 1998 \\
\hline Tom-26 & Tamarillo & Guarne, Antioquia & Fruit & 1998 \\
\hline Tom-27 & Tamarillo & Guarne, Antioquia & Flower & 1998 \\
\hline Tom-28 & Tamarillo & Guarne, Antioquia & Flower & 1998 \\
\hline Tom-30 & Tamarillo & Don Matias, Antioquia & Leaf & 1998 \\
\hline Tom-31 & Tamarillo & Guarne, Antioquia & Fruit & 1998 \\
\hline Tom-32 & Tamarillo & Guarne, Antioquia & Fruit & 1998 \\
\hline Tom-38 & Tamarillo & Guarne, Antioquia & Flower & 1998 \\
\hline Tom-39 & Tamarillo & Santa Rosa, Antioquia & Fruit & 1998 \\
\hline Tom-41 & Tamarillo & San Vicente, Antioquia & Leaf & 1998 \\
\hline Tom-42 & Tamarillo & Don Matias, Antioquia & Fruit & 1998 \\
\hline Tom-43 & Tamarillo & Carmen de Viboral, Antioquia & Fruit & 1998 \\
\hline Tom-44 & Tamarillo & San Vicente, Antioquia & Fruit & 1998 \\
\hline Tom-45 & Tamarillo & Urrao, Antioquia & Fruit & 1998 \\
\hline Tom-46 & Tamarillo & Urrao, Antioquia & Fruit & 1998 \\
\hline Tom-47 & Tamarillo & Don Matias, Antioquia & Fruit & 1998 \\
\hline Tom-48 & Tamarillo & Don Matias, Antioquia & Flower & 1998 \\
\hline Tom-49 & Tamarillo & Rionegro, Antioquia & Fruit & 1998 \\
\hline Tom-50 & Tamarillo & Don Matias, Antioquia & Fruit & 1998 \\
\hline Tom-54 & Tamarillo & La Unión, Antioquia & Fruit & 1998 \\
\hline Tom-55 & Tamarillo & La Unión, Antioquia & Fruit & 1998 \\
\hline Tom-57 & Tamarillo & La Unión, Antioquia & Flower & 1998 \\
\hline Tom-60 & Tamarillo & La Unión, Antioquia & Fruit & 1998 \\
\hline Tom-80 & Tamarillo & Santa Rosa, Antioquia & Flower & 1998 \\
\hline
\end{tabular}

a Tom = tomato tree or tamarillo (Solanum betacea), Pass = Passiflora , different species, and Man = mango (Mangifera indica L.).

${ }^{\mathrm{b}}$ Locations of commercial and backyard orchards in Colombia from which isolates were obtained. 
AGCAG (26), AGGAGGAGGAGGAGG, GACACGACACGACAC (20), and GACAGACAGACAGACA (30). In the text, these primers have been designated $(\mathrm{CAG})_{5},(\mathrm{AGG})_{5},(\mathrm{GACAC})_{3}$, and $(\mathrm{GACA})_{4}$, respectively. For RAPD-PCR, a 10-base oligomer primer, OPF-08 (GGGATATCGG) also was used (Operon Technologies, Alameda, CA). Universal PCR primers were used (ITS1, TCCGTAGGTGAACCTGCGG and ITS4, TCCTCCGCTTATTGATATGC) for amplification of the ITS1 and ITS2 regions between the small and large nuclear rDNA, including the 5.8S rDNA, as described by White et al. (31). PCR primers for taxonspecific amplification included the ITS4 primer coupled with specific primers for $C$. acutatum (CaInt2) (GGGGAAGCCTCTCGCGG) and C. gloeosporioides (CgInt) (GGCCTCCCGCCTCCGGGCGG) (6). PCR primers for specific amplification of the passiflora population (including isolates TOM-6 and Man-76) of Colletotrichum spp. (not amplified with the CaInt2 and CgInt primers) included the ITS4 primer coupled with primer Col1 (GCCGTCCCCTGAAAAG), synthesized from the ITS1 region corresponding with the $C a \mathrm{Int} 2$ and $C g$ Int primers. PCR reactions were performed in a total volume of $20 \mu \mathrm{l}$, containing 10 to $100 \mathrm{ng}$ of genomic DNA, $50 \mathrm{mM} \mathrm{KCl}, 10 \mathrm{mM}$ Tris- $\mathrm{HCl}, 0.2 \mathrm{mM}$ each of dATP, dCTP, dGTP, and dTTP, $1.5 \mathrm{mM} \mathrm{MgCl} 2,1$ unit of
Taq DNA polymerase (Promega, Corp., Madison, WI) and $1 \mu \mathrm{M}$ primer. All the reactions were incubated in a PTC-100 thermocycler (MJ Research, Inc., Watertown, MA) starting with 5 min of denaturation at $95^{\circ} \mathrm{C}$. For ap-PCR, this was followed by 30 cycles consisting of $30 \mathrm{~s}$ at $95^{\circ} \mathrm{C}, 30 \mathrm{~s}$ at either $60^{\circ} \mathrm{C}$ (for $(\mathrm{CAG})_{5}$ and $\left.(\mathrm{AGG})_{5}\right)$ or $48^{\circ} \mathrm{C}$ (for $(\mathrm{GACA})_{4}$ and $(\mathrm{GACAC})_{3}$ ) and $1.5 \mathrm{~min}$ at $72^{\circ} \mathrm{C}$. For RAPD-PCR with OPF-08 primer, denaturation was followed by 44 cycles consisting of $1 \mathrm{~min}$ at $94^{\circ} \mathrm{C}, 1 \mathrm{~min}$ at $34^{\circ} \mathrm{C}$, and $2 \mathrm{~min}$ at $72^{\circ} \mathrm{C}$. For rDNA amplification, denaturation was followed by 40 cycles consisting of $30 \mathrm{~s}$ at $95^{\circ} \mathrm{C}, 30 \mathrm{~s}$ at $50^{\circ} \mathrm{C}$, and $1.5 \mathrm{~min}$ at $72^{\circ} \mathrm{C}$. For taxon-specific PCR, reactions were performed under conditions for primer $(\mathrm{CAG})_{5}$, with $0.5 \mu \mathrm{M}$ ITS4 primer coupled with either $0.5 \mu \mathrm{M}$ primer $C a \mathrm{Int} 2$ for $C$. acutatumspecific detection or $0.5 \mu \mathrm{M}$ primer $C g$ Int for $C$. gloeosporioidesspecific detection. For Col1-specific PCR, the reaction was performed using $0.5 \mu \mathrm{M}$ primer Coll coupled with $0.5 \mu \mathrm{M}$ primer ITS4, with denaturation of $5 \mathrm{~min}$ at $95^{\circ} \mathrm{C}$, followed by 40 cycles consisting of $30 \mathrm{~s}$ at $95^{\circ} \mathrm{C}, 30 \mathrm{~s}$ at $65^{\circ} \mathrm{C}$, and $1.5 \mathrm{~min}$ at $72^{\circ} \mathrm{C}$. Amplification products were separated in agarose gels $(1.5 \%$, $\mathrm{wt} / \mathrm{vol} ; 15-\mathrm{cm}$ width by $10-\mathrm{cm}$ length) in Tris-acetate-EDTA buffer (27) electrophoresed at $80 \mathrm{~V}$ for $2 \mathrm{~h}$. All PCR experiments were repeated at least four times with identical results

TABLE 1. (continued from preceding page)

\begin{tabular}{|c|c|c|c|c|}
\hline Isolate $^{\mathrm{a}}$ & Host species & Location $^{\mathrm{b}}$ & Tissue & Collection date \\
\hline Tom-90 & Tamarillo & Don Matias, Antioquia & Leaf & 1998 \\
\hline Tom-98 & Tamarillo & Don Matias, Antioquia & Fruit & 1998 \\
\hline Tom-99 & Tamarillo & Don Matias, Antioquia & Branch & 1998 \\
\hline Tom-104 & Tamarillo & Urrao, Antioquia & Fruit & 1998 \\
\hline Tom-106 & Tamarillo & Guarne, Antioquia & Fruit & 1998 \\
\hline Tom-109 & Tamarillo & Urrao, Antioquia & Fruit & 1998 \\
\hline Tom-110 & Tamarillo & Don Matias, Antioquia & Fruit & 1998 \\
\hline Tom-112 & Tamarillo & San Vicente, Antioquia & Fruit & 1998 \\
\hline Pass-19 & Passiflora mollissima & Rionegro, Antioquia & Leaf & 1999 \\
\hline Pass-20 & Hybrid P. mollissima & Rionegro, Antioquia & Fruit & 1999 \\
\hline Pass-33 & Acc. 396097 & Rionegro, Antioquia & Fruit & 1999 \\
\hline Pass-34 & P. mollissima & Rionegro, Antioquia & Fruit & 1999 \\
\hline Pass-35 & Passiflora spp. & Rionegro, Antioquia & Leaf & 1999 \\
\hline Pass-36 & P. alnifolia & Rionegro, Antioquia & Leaf & 1999 \\
\hline Pass-40 & P. edulis & Rionegro, Antioquia & Fruit & 1999 \\
\hline Pass-52 & Passiflora spp. & Rionegro, Antioquia & Leaf & 1999 \\
\hline Pass-55 & P. edulis & Rionegro, Antioquia & Leaf & 1999 \\
\hline Pass-61 & P. edulis & Rionegro, Antioquia & Leaf & 1999 \\
\hline Pass-62 & Passiflora spp. & Rionegro, Antioquia & Leaf & 1999 \\
\hline Pass-63 & Acc. 396047 & Rionegro, Antioquia & Leaf & 1999 \\
\hline Pass-64 & P. alnifolia & Rionegro, Antioquia & Leaf & 1999 \\
\hline Pass-65 & P. cuadragelis & Rionegro, Antioquia & Fruit & 1999 \\
\hline Pass-66 & Passiflora spp. & Rionegro, Antioquia & Branch & 1999 \\
\hline Pass-67 & P. maliformis & Rionegro, Antioquia & Leaf & 1999 \\
\hline Pass-68 & Passiflora spp. & Rionegro, Antioquia & Leaf & 1999 \\
\hline Pass-96 & P. cuadragelis & Santa Fé de Antioquia, Antioquia & Fruit & 1999 \\
\hline Pass-101 & P. ligularis & Rionegro, Antioquia & Leaf & 1999 \\
\hline Pass-102 & P. adenopoda & Rionegro, Antioquia & Leaf & 1999 \\
\hline Pass-103 & P. assiflora spp. & Rionegro, Antioquia & Leaf & 1999 \\
\hline Pass-107 & P. mollissima & Rionegro, Antioquia & Leaf & 1999 \\
\hline Pass-108 & P. ligularis & Rionegro, Antioquia & Leaf & 1999 \\
\hline Pass-113 & P. alnifolia & Rionegro, Antioquia & Leaf & 1999 \\
\hline Pass-114 & P. ligularis & Rionegro, Antioquia & Leaf & 1999 \\
\hline Pass-115 & P. moliformis & Rionegro, Antioquia & Leaf & 1999 \\
\hline Man-51 & Mangifera indica $\mathrm{cv}$. Heyden & Sevilla, Magdalena & Fruit & 1998 \\
\hline Man-53 & M. indica cv. Criollo & La Pintada, Antioquia & Leaf & 2000 \\
\hline Man-59 & M. indica $\mathrm{cv}$. Corazón & Santa Fé de Antioquia, Antioquia & Leaf & 1999 \\
\hline Man-69 & M. indica $\mathrm{cv}$. Heyden & Santa Fé de Antioquia, Antioquia & Flower & 1999 \\
\hline Man-70 & M. indica cv. Criollo & Barbosa, Antioquia & Fruit & 1999 \\
\hline Man-72 & M. indica cv. Papaya & Malagana, Bolivar & Fruit & 1998 \\
\hline Man-73 & M. indica cv. Azúcar & Sevilla, Magdalena & Fruit & 1998 \\
\hline Man-75 & M. indica cv. Azúcar & Cerete, Sucre & Fruit & 1998 \\
\hline Man-76 & M. indica cv. Criollo & Barbosa, Antioquia & Fruit & 1999 \\
\hline Man-82 & M. indica $\mathrm{cv}$. Irwin & Turipana, Cordoba & Fruit & 1998 \\
\hline Man-87 & M. indica $\mathrm{cv}$. Manzanita & Malagana, Bolivar & Fruit & 1998 \\
\hline Man-91 & Unknown & Santa Fé de Antioquia, Antioquia & Fruit & 1998 \\
\hline Man-94 & Unknown & Tierra Alta, Cordoba & Fruit & 1998 \\
\hline Man-95 & M. indica cv. Criollo & La Pintada, Antioquia & Flower & 2000 \\
\hline Man-97 & M. indica $\mathrm{cv}$. Sufaida verde & Santa Fé de Antioquia, Antioquia & Leaf & 1999 \\
\hline
\end{tabular}


being achieved. Variation according to ap-PCR, RAPD-PCR, and A+T-rich DNA analyses (described below) was not quantified, but diversity was interpreted according to overall banding patterns.

A+T-rich DNA analyses. A+T-rich DNA was analyzed by Hae III digestion of total genomic DNA, which cleaves DNA at GGCC sites. HaeIII digests nuclear DNA to fragments mainly less than $2 \mathrm{~kb}$ in size, whereas A+T-rich sequences are cleaved less frequently $(15,18)$. A+T-rich DNA is partially associated with the mitochondrial genome, although contaminating nuclear A+T-rich DNA also may be present. Procedures used for HaeIII restriction enzyme digestion and agarose gel electrophoresis were similar to those previously described (15).

Sequencing procedure. PCR-amplified rDNA products from representative isolates of Colletotrichum spp., using the primer pair ITS1 and ITS4 (31), resulted in a product of $\approx 560 \mathrm{bp}$, which was extracted from agarose gels using the Jetsorb kit (Genomed GmbH, Germany). The Big Dye Terminator DNA sequencing kit (Perkin-Elmer Inc., Branchburg, NJ) was used for determining sequence of the ITS1-2 regions (31). The sequence was determined using an ABI prism 377 DNA sequencer (Applied Biosystem Inc., Foster City, CA) and was performed by the Molecular Biology Center, Ness Ziona, Israel.

Phylogenetic analysis. Analyses of ITS sequences were carried out using the ARB program package (29). Alignment of sequences was performed with the ARB automated alignment tool and alignments were refined manually. Phylogenetic analyses were performed by applying ARB parsimony, distance matrix, and maximum-likelihood methods. To determine the robustness of phylogenetic trees, analyses were performed both on the original data set and on a data set from which highly variable positions were removed by use of a $50 \%$ conservation filter for the members of Colletotrichum, to reduce potential tree artifacts that may result from multiple base changes. Analysis was conducted on the ITS2 sequences of DNA (which is more informative as far as diversity is concerned than ITS1 alone) (14) from 15 representative isolates of Colletotrichum spp. from tamarillo (Tom-6, Tom9, Tom-12, and Tom-21), passiflora (Pass-33, Pass-35, Pass-52, Pass-55, Pass-62, Pass-65, Pass-67, and Pass-103), and mango (Man-53, Man-69, and Man-76). Complete ITS1-2 sequences of the isolates were submitted to GenBank; accession numbers are shown in Table 3. Additional Colletotrichum sequences retrieved from the GenBank are included in this study for comparison (Table 3).

\section{RESULTS}

Morphological characterization of Colletotrichum isolates. Isolates from tamarillo (Tom-6; IMI 386922), passiflora (Pass-35; IMI 386920), and mango (Man-76; IMI 386921) that were not clearly defined by molecular methods were identified and characterized within the $C$. gloeosporioides species aggregate by morphological criteria by P. F. Cannon (CABI Bioscience, Egham, Surrey, UK); however, several features are unusual (Table 2). For example, Pass-35 conidia possess an unusually high length/ breadth ratio and the appressoria appear to be formed from nodose brown swellings, and Man-76 appressoria are also complex and compound, distinguishing these two strains from typical C. gloeosporioides. In addition, isolates Tom-9 from tamarillo, Pass-62 from passiflora, and Man-75 from mango were characterized by us (Table 2). Conidia from Tom-9 were typical for $C$. acutatum, possessing tapering, acute ends, while those from Man-75 were typical for C. gloeosporioides, possessing cylindrical, rounded ends. Pass-62 was similar in morphology to isolate Man-76.

Species-specific primer analyses. DNA from 97 Colletotrichum spp. isolates collected from tamarillo $(n=54)$, passiflora $(n=26)$, mango $(n=15)$, and representatives of $C$. acutatum (isolate TUT-5954) and C. gloeosporioides (isolate AVO-37-4B), was amplified with the taxon-specific primers for $C$. acutatum (CaInt2) and C. gloeosporioides ( $C g \mathrm{Int})$ species as well as with Col1 (Table 4). PCR reactions with representative isolates of each population are presented in Figure 1. A 490-bp DNA fragment was amplified with the $C$. acutatum-specific primers $C a$ Int 2 and ITS4 from all tamarillo isolates (except Tom-6) and the representative C. acutatum TUT-5954 isolate; however, no amplification product was evident with any of the passiflora and mango isolates (Fig. 1A; Table 4). A 450-bp DNA fragment was amplified with the $C$. gloeosporioides-specific primers $C g$ Int and ITS4 from 14 mango isolates and the representative C. gloeosporioides AVO-37-4B isolate, whereas no amplification product was observed from any of the passiflora isolates, isolate Tom-6 from tamarillo, or isolate Man-76 from mango (Fig. 1B; Table 4). A 520-bp DNA fragment was amplified from all passiflora isolates (except Pass-35), isolate Tom-6 from tamarillo, and isolate Man-76 from mango with Col1, the new primer designed for amplification of DNA from this unique population of Colletotrichum, but no amplification product was observed with the other tamarillo, mango, or representative $C$. gloeosporioides and C. acutatum isolates (Fig. 1C; Table 4). Specific amplification products indicate that 53 of the 54 tested

TABLE 2. Conidia type, colony morphology in culture, and species identification of representative isolates of Colletotrichum spp. from tamarillo, mango, and passiflora species in Colombia

\begin{tabular}{|c|c|c|c|c|}
\hline Isolate $^{\mathrm{a}}$ & Host & Conidia morphology and size & Colony morphology in culture & Species designation \\
\hline Tom-6 (IMI 386922) & Tamarillo & $\begin{array}{l}\text { Oblong, one end tapered and the other round, } \\
\text { measuring } 13.0 \text { to } 18.0 \text { by } 4.4 \text { to } 6.6 \mu \mathrm{m}\end{array}$ & $\begin{array}{l}\text { White mycelium, turning dark salmon with age } \\
\text { due to proliferation of spore masses; no } \\
\text { sclerotia present; setae present but scarce }\end{array}$ & Colletotrichum sp. ${ }^{b}$ \\
\hline Tom-9 & Tamarillo & $\begin{array}{l}\text { Fusiform, tapered at both ends, } \\
\text { measuring } 10.3 \text { to } 18.7 \text { by } 3.7 \text { to } 5.6 \mu \mathrm{m}\end{array}$ & $\begin{array}{l}\text { White mycelium turning gray and powdery } \\
\text { with pink spore masses, salmon in color, } \\
\text { produced outward in circles from the center } \\
\text { of the culture }\end{array}$ & C. acutatum \\
\hline Pass-35 (IMI 386920) & Passiflora & $\begin{array}{l}\text { Fusiform with rounded ends, } \\
\text { measuring } 12.0 \text { to } 16.0 \text { by } 5.0 \text { to } 7.0 \mu \mathrm{m}\end{array}$ & $\begin{array}{l}\text { White mycelium with pink spore masses, } \\
\text { salmon in color, originating from large black } \\
\text { sclerotia }\end{array}$ & Colletotrichum sp. ${ }^{\mathrm{b}}$ \\
\hline Pass-62 & Passiflora & $\begin{array}{l}\text { Fusiform with rounded ends, } \\
\text { measuring } 12.0 \text { to } 16.0 \text { by } 5.0 \text { to } 7.0 \mu \mathrm{m}\end{array}$ & $\begin{array}{l}\text { White cottony mycelium becoming gray with } \\
\text { pink spore masses, salmon in color; large } \\
\text { black sclerotia }\end{array}$ & Colletotrichum sp. ${ }^{\mathrm{b}}$ \\
\hline Man-76 (IMI 386921) & Mango & $\begin{array}{l}\text { Oblong with rounded ends, } \\
\text { measuring } 11.0 \text { to } 18.0 \text { by } 5.0 \text { to } 7.0 \mu \mathrm{m}\end{array}$ & $\begin{array}{l}\text { White cottony mycelium with pink spore } \\
\text { masses, salmon in color; large black } \\
\text { sclerotia }\end{array}$ & Colletotrichum sp. ${ }^{\mathrm{b}}$ \\
\hline Man-75 & Mango & $\begin{array}{l}\text { Cylindrical and lenticular, } \\
\text { measuring } 12.0 \text { to } 14.5 \text { by } 5.0 \text { to } 7.0 \mu \mathrm{m}\end{array}$ & $\begin{array}{l}\text { White mycelium becoming gray and aerial with } \\
\text { pink spore masses, salmon in color mainly at } \\
\text { the center of the colony }\end{array}$ & C. gloeosporioides \\
\hline
\end{tabular}

${ }^{a}$ Isolates deposited in the culture collection of CABI Bioscience were designated with an additional code as indicated in parentheses.

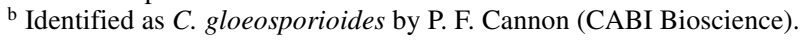


tamarillo isolates are C. acutatum and 14 of the 15 mango isolates are $C$. gloeosporioides, whereas the passiflora isolates (together with Tom-6 from tamarillo and Man-76 from mango) belong to a population of Colletotrichum as yet unidentified. DNA of isolate Pass-35 from passiflora did not amplify with any of the primers.

Ap-PCR and RAPD analyses. Amplification products were obtained from all 95 (tamarillo, passiflora, and mango) isolates tested with the microsatellite derived primers $(\mathrm{CAG})_{5},(\mathrm{AGG})_{5}$, $(\mathrm{GACA})_{4}$, and $(\mathrm{GACAC})_{3}$ and random primer OPF-08. Among the tested isolates from tamarillo, a low level of variability was observed, which would be consistent with a clonally propagating population. Mango isolates were more variable and the population from passiflora also was diverse when comparing isolates within each population. Isolates from passiflora were equally variable when comparing representative isolates between the tamarillo and mango populations. Gels showing diversity among and between representative isolates of each population from tamarillo, passiflora, and mango, using the respective primers (AGG) $)_{5}$ and $(\mathrm{GACA})_{4}$, are presented (Fig. 2A and B). Similar degrees of diversity within and among populations were obtained using primers $(\mathrm{CAG})_{5},(\mathrm{GACAC})_{3}$, and OPF-08 (data not shown).

A+T-rich DNA analyses. A+T-rich DNA analysis was carried out by HaeIII digestion of total DNA from 16 representative isolates, used previously, of Colletotrichum from tamarillo, passiflora, and mango (Fig. 3). Results obtained using this method corroborated the findings observed with species-specific, microsatellite, and random primer analyses, whereby isolates from tamarillo belong to a homogeneous population but isolates from mango and passiflora showed a high level of variation. A+T-rich DNA analysis again allowed grouping of the tamarillo isolates within a single population, differentiating them from those identified as $C$. gloeosporioides. At the same time, clonality of the $C$.

TABLE 3. Internal transcribed spacer 1 and 2 sequences of Colletotrichum isolates used in this study

\begin{tabular}{|c|c|c|c|}
\hline Species & Isolate & Host & EMBL accession \\
\hline C. trichellum & $89489^{a}$ & Hedera helix & Z 33033 \\
\hline C. fructigenum & $4885^{\mathrm{a}}$ & Acmena smithii & Z 32907 \\
\hline C. orbiculare & $172.59^{\mathrm{a}}$ & Cucumis sativus & Z 33379 \\
\hline C. destructivum & $319^{a}$ & Medicago sativa & Z 32940 \\
\hline C. graminicola & $\mathrm{DR} 1^{\mathrm{b}}$ & Poa аппиа & AF 059676 \\
\hline C. gloeosporioides & $\mathrm{CG} 231^{\mathrm{c}}$ & Fragaria $\times$ ananassa & AF 272780 \\
\hline C. gloeosporioides & AVO-37-4B & Persea americana & AF 207792 \\
\hline C. gloeosporioides & APL $7^{\mathrm{c}}$ & Malus domestica & AF 272779 \\
\hline C. acutatum & TUT 5954c & Fragaria $\times$ ananassa & AF 207794 \\
\hline C. acutatum & $\mathrm{PCN} 5^{\mathrm{c}}$ & Carya illinoensis & AF 272786 \\
\hline C. acutatum & $\mathrm{PCH} 8^{\mathrm{c}}$ & Prunus persica & AF 272788 \\
\hline C. acutatum & ANE-HV83C & Anemone coronaria & AF 272782 \\
\hline C. acutatum & STR $3^{\mathrm{c}}$ & Fragaria $\times$ ananassa & AF 272784 \\
\hline C. acutatum & ALM-US-4 ${ }^{c}$ & Prunus dulcis & AF 207793 \\
\hline C. acutatum & IMI $223120^{c}$ & Anemone coronaria & AF 272783 \\
\hline C. acutatum & APL $2^{c}$ & Malus domestica & AF 272787 \\
\hline C. acutatum & ANE-NL12A ${ }^{c}$ & Anemone coronaria & AF 272781 \\
\hline C. acutatum & IMI $345026^{\mathrm{c}}$ & Fragaria $\times$ ananassa & AF 272789 \\
\hline Colletotrichum sp. & ALM-KSH-10 & Prunus dulcis & AF 207791 \\
\hline C. acutatum & Tom-9d & Solanum betacea & AF 521205 \\
\hline C. acutatum & Tom- $12^{\mathrm{d}}$ & Solanum betacea & AF 521210 \\
\hline C. acutatum & Tom- $21^{\mathrm{d}}$ & Solanum betacea & AF 521196 \\
\hline C. gloeosporioides & Man-53 & Mangifera indica sp. & AF 521198 \\
\hline C. gloeosporioides & Man-69d & Mangifera indica $\mathrm{sp}$. & AF 521209 \\
\hline Colletotrichum sp. & Man-76d & Mangifera indica $\mathrm{sp}$. & AF 521204 \\
\hline Colletotrichum sp. & Pass- $33^{d}$ & Passiflora sp. & AF 521202 \\
\hline Colletotrichum sp. & Pass- $52^{d}$ & Passiflora sp. & AF 521206 \\
\hline Colletotrichum sp. & Pass $-55^{d}$ & Passiflora sp. & AF 521199 \\
\hline Colletotrichum sp. & Pass-62d & Passiflora sp. & AF 521203 \\
\hline Colletotrichum sp. & Pass- $65^{\mathrm{d}}$ & Passiflora sp. & AF 521200 \\
\hline Colletotrichum sp. & Pass- $67^{d}$ & Passiflora sp. & AF 521208 \\
\hline Colletotrichum sp. & Pass- $103^{\mathrm{d}}$ & Passiflora $\mathrm{sp}$ & AF 521201 \\
\hline Colletotrichum sp. & Tom-6 $6^{\mathrm{d}}$ & Solanum betacea & AF 521207 \\
\hline Colletotrichum sp. & Pass-35 & Passiflora sp. & AF 521197 \\
\hline C. acutatum & BBA $62126^{\mathrm{e}}$ & Coffea arabica & AJ 301924 \\
\hline Colletotrichum sp. & BBA70539e & Coelogyne sp. & AJ 301939 \\
\hline C. gloeosorioides & BBA71334 & Citrus sp. & AJ 301974 \\
\hline C. lupini & $\mathrm{BBA} 71330^{\mathrm{e}}$ & Urtica dioica & AJ 301975 \\
\hline C. lupini & BBA71249f & Lupinus albus & AJ 301959 \\
\hline C. truncatum & BBA70523 ${ }^{\mathrm{f}}$ & Hosta sp. & AJ 301937 \\
\hline Glomerella cingulata & BBA65797f & Syringa vulgaris & AJ 301925 \\
\hline Colletotrichum sp. & AHU9748g & Unknown & AB 076800 \\
\hline C. dematium & IMI-080025 h & Unknown & AB 046608 \\
\hline C. linicola & CBS $172.51^{\mathrm{h}}$ & Unknown & AB 046608 \\
\hline C. truncatum & $9969473^{\mathrm{i}}$ & Lens culinaris & AF 451902 \\
\hline C. truncatum & UQ349i & Lens culinaris & AF 451909 \\
\hline
\end{tabular}

a Isolates sequenced by Sreenivasaprasad et al. (28).

${ }^{\mathrm{b}}$ Isolate sequenced by Travanty et al. (EMBL direct submission).

c Isolates sequenced by Freeman et al. (13).

d Isolates sequenced by the authors.

e Isolate sequenced by Hagedorn et al. (EMBL direct submission).

${ }^{\mathrm{f}}$ Isolate sequenced by Nirenberg et al. (24).

$\mathrm{g}$ Isolate sequenced by Tanaka et al. (EMBL direct submission).

${ }^{\mathrm{h}}$ Isolate sequenced by J. Moriwaki and T. Tsukiboshi (EMBL direct submission).

${ }^{\mathrm{i}}$ Isolate sequenced by R. Ford and P. W. J. Taylor (EMBL direct submission). 
acutatum tamarillo population, represented in this case by isolates Tom-9, Tom-12, and Tom-21, was further verified (Fig. 3).

Sequence analyses. In order to verify the species identification performed using taxon-specific primers, a set of 15 representative isolates from tamarillo, mango, and passiflora was analyzed by comparing the ITS2 sequences of these Colletotrichum isolates with previously reported sequences of other Colletotrichum spp. Sequence analysis was conducted on isolates Tom-9, Tom-12, and Tom-21, identified as C. acutatum; isolates Man-53, Man-69, and Man-75, identified as C. gloeosporioides; and isolates Tom-6, Man-76, Pass-33, Pass- 35, Pass-52, Pass-55, Pass-65, Pass-62, Pass-67, and Pass-103, not corresponding to either C. acutatum or C. gloeosporioides according to the taxon-specific analysis, but classified as Colletotrichum spp. by morphological criteria. Sequence data of the isolates TUT 5954 of $C$. acutatum and AVO37-4B of C. gloeosporioides were used as references together with the sequence data previously reported for additional representative isolates of the species: C. trichellum, C. fructigenum, $C$. orbiculare, $C$. acutatum, C. lupini, C. destructivum, C. truncatum, $C$. gloeosporioides, C. graminicola, C. dematium, C. truncatum, $C$. linicola, and C. trifolii (Table 3).

Phylogenetic analyses of the ITS2 sequence performed by applying ARB parsimony, distance matrix, and maximum-likelihood methods produced similar tree topologies. Removing highly variable positions from the sequence analysis did not affect tree topology. Sequence analysis confirmed species identification for the tamarillo population as $C$. acutatum and grouped them with $C$. lupini isolates within a new subgroup $\mathrm{V}$ of $C$. acutatum (Fig. 4). ITS2 sequence placed the mango population within the typical $C$. gloeosporioides cluster with isolates from avocado and apple. However, the passiflora isolates and Tom-6 and Man-76 from tamarillo and mango, respectively, were placed within a separate cluster containing three recently submitted sequences of Colletotrichum isolates (BBA 70539, BBA 71334, and AHU 9748) (Table

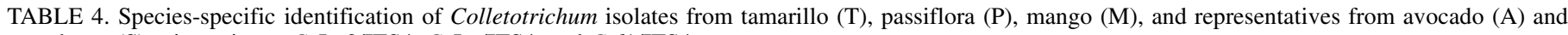
strawberry (S) using primers CaInt2/ITS4, CgInt/ITS4, and Col1/ITS4 ${ }^{a}$

\begin{tabular}{|c|c|c|c|c|c|c|c|c|c|c|c|}
\hline \multirow[b]{2}{*}{ Host } & \multirow[b]{2}{*}{ Isolate } & \multicolumn{3}{|c|}{ Primer reaction } & \multirow[b]{2}{*}{ Species } & \multirow[b]{2}{*}{ Host } & \multirow[b]{2}{*}{ Isolate } & \multicolumn{3}{|c|}{ Primer reaction } & \multirow[b]{2}{*}{ Species } \\
\hline & & CaInt2 & $C g$ Int & Col1 & & & & CaInt2 & $C g$ Int & Col1 & \\
\hline $\mathrm{T}$ & Tom-2 & + & - & - & C. acutatum & $\mathrm{T}$ & Tom-98 & + & - & - & C. acutatum \\
\hline $\mathrm{T}$ & Tom-3 & + & - & - & C. acutatum & $\mathrm{T}$ & Tom-99 & + & - & - & C. acutatum \\
\hline $\mathrm{T}$ & Tom-4 & + & - & - & C. acutatum & $\mathrm{T}$ & Tom-104 & + & - & - & C. acutatum \\
\hline $\mathrm{T}$ & Tom-5 & + & - & - & C. acutatum & $\mathrm{T}$ & Tom-106 & + & - & - & C. acutatum \\
\hline $\mathrm{T}$ & Tom-6 & - & - & + & C. acutatum & $\mathrm{T}$ & Tom-109 & + & - & - & C. acutatum \\
\hline $\mathrm{T}$ & Tom-7 & + & - & - & C. acutatum & $\mathrm{T}$ & Tom-110 & + & - & - & C. acutatum \\
\hline $\mathrm{T}$ & Tom-8 & + & - & - & C. acutatum & $\mathrm{P}$ & Pass-19 & - & - & + & Colletotrichum sp. \\
\hline $\mathrm{T}$ & Tom-9 & + & - & - & C. acutatum & $\mathrm{P}$ & Pass-20 & - & - & + & Colletotrichum sp. \\
\hline $\mathrm{T}$ & Tom-10 & + & - & - & C. acutatum & $\mathrm{P}$ & Pass-33 & - & - & + & Colletotrichum sp. \\
\hline $\mathrm{T}$ & Tom-11 & + & - & - & C. acutatum & $\mathrm{P}$ & Pass-34 & - & - & + & Colletotrichum sp. \\
\hline $\mathrm{T}$ & Tom-12 & + & - & - & C. acutatum & $\mathrm{P}$ & Pass-35 & - & - & - & Colletotrichum sp. \\
\hline $\mathrm{T}$ & Tom-13 & + & - & - & C. acutatum & $\mathrm{P}$ & Pass-36 & - & - & + & Colletotrichum sp. \\
\hline $\mathrm{T}$ & Tom-14 & + & - & - & C. acutatum & $\mathrm{P}$ & Pass-40 & - & - & + & Colletotrichum sp. \\
\hline $\mathrm{T}$ & Tom-15 & + & - & - & C. acutatum & $\mathrm{P}$ & Pass-52 & - & - & + & Colletotrichum sp. \\
\hline $\mathrm{T}$ & Tom-16 & + & - & - & C. acutatum & $\mathrm{P}$ & Pass-55 & - & - & + & Colletotrichum sp. \\
\hline $\mathrm{T}$ & Tom-17 & + & - & - & C. acutatum & $\mathrm{P}$ & Pass-61 & - & - & + & Colletotrichum sp. \\
\hline $\mathrm{T}$ & Tom-18 & + & - & - & C. acutatum & $\mathrm{P}$ & Pass-62 & - & - & + & Colletotrichum sp. \\
\hline $\mathrm{T}$ & Tom-21 & + & - & - & C. acutatum & $\mathrm{P}$ & Pass-63 & - & - & + & Colletotrichum sp. \\
\hline $\mathrm{T}$ & Tom-22 & + & - & - & C. acutatum & $\mathrm{P}$ & Pass-64 & - & - & + & Colletotrichum sp. \\
\hline $\mathrm{T}$ & Tom-23 & + & - & - & C. acutatum & $\mathrm{P}$ & Pass-65 & - & - & + & Colletotrichum sp. \\
\hline $\mathrm{T}$ & Tom-24 & + & - & - & C. acutatum & $\mathrm{P}$ & Pass-66 & - & - & + & Colletotrichum sp. \\
\hline $\mathrm{T}$ & Tom-25 & + & - & - & C. acutatum & $\mathrm{P}$ & Pass-67 & - & - & + & Colletotrichum sp. \\
\hline $\mathrm{T}$ & Tom-26 & + & - & - & C. acutatum & $\mathrm{P}$ & Pass-68 & - & - & + & Colletotrichum sp. \\
\hline $\mathrm{T}$ & Tom-27 & + & - & - & C. acutatum & $\mathrm{P}$ & Pass-96 & - & - & + & Colletotrichum sp. \\
\hline $\mathrm{T}$ & Tom-28 & \pm & - & - & C. acutatum & $\mathrm{P}$ & Pass-101 & - & - & + & Colletotrichum sp. \\
\hline $\mathrm{T}$ & Tom-30 & \pm & - & - & C. acutatum & $\mathrm{P}$ & Pass-102 & - & - & + & Colletotrichum sp. \\
\hline $\mathrm{T}$ & Tom-31 & + & - & - & C. acutatum & $\mathrm{P}$ & Pass-103 & - & - & + & Colletotrichum sp. \\
\hline $\mathrm{T}$ & Tom-32 & \pm & - & - & C. acutatum & $\mathrm{P}$ & Pass-107 & - & - & + & Colletotrichum sp. \\
\hline $\mathrm{T}$ & Tom-38 & + & - & - & C. acutatum & $\mathrm{P}$ & Pass-108 & - & - & + & Colletotrichum sp. \\
\hline $\mathrm{T}$ & Tom-39 & + & - & - & C. acutatum & $\mathrm{P}$ & Pass-113 & - & - & + & Colletotrichum sp. \\
\hline $\mathrm{T}$ & Tom-41 & + & - & - & C. acutatum & $\mathrm{P}$ & Pass-114 & - & - & + & Colletotrichum sp. \\
\hline $\mathrm{T}$ & Tom-42 & + & - & - & C. acutatum & $\mathrm{P}$ & Pass-115 & - & - & + & Colletotrichum sp. \\
\hline $\mathrm{T}$ & Tom-43 & + & - & - & C. acutatum & M & Man-51 & - & + & - & C. gloeosporioides \\
\hline $\mathrm{T}$ & Tom-44 & + & - & - & C. acutatum & $\mathrm{M}$ & Man-53 & - & + & - & C. gloeosporioides \\
\hline $\mathrm{T}$ & Tom-45 & \pm & - & - & C. acutatum & $\mathrm{M}$ & Man-59 & - & + & - & C. gloeosporioides \\
\hline $\mathrm{T}$ & Tom-46 & + & - & - & C. acutatum & M & Man-69 & - & + & - & C. gloeosporioides \\
\hline $\mathrm{T}$ & Tom-47 & \pm & - & - & C. acutatum & M & Man-70 & - & + & - & C. gloeosporioides \\
\hline $\mathrm{T}$ & Tom-48 & + & - & - & C. acutatum & M & Man-72 & - & + & - & C. gloeosporioides \\
\hline $\mathrm{T}$ & Tom-49 & + & - & - & C. acutatum & M & Man-73 & - & + & - & C. gloeosporioides \\
\hline $\mathrm{T}$ & Tom-50 & + & - & - & C. acutatum & M & Man-75 & - & \pm & - & C. gloeosporioides \\
\hline $\mathrm{T}$ & Tom-54 & + & - & - & C. acutatum & M & Man-76 & - & - & + & Colletotrichum $\mathrm{sp}$ \\
\hline $\mathrm{T}$ & Tom-55 & + & - & - & C. acutatum & M & Man-82 & - & + & - & C. gloeosporioides \\
\hline $\mathrm{T}$ & Tom-56 & + & - & - & C. acutatum & M & Man-87 & - & + & - & C. gloeosporioides \\
\hline $\mathrm{T}$ & Tom-57 & + & - & - & C. acutatum & $\mathrm{M}$ & Man-91 & - & + & - & C. gloeosporioides \\
\hline $\mathrm{T}$ & Tom-60 & + & - & - & C. acutatum & M & Man-94 & - & + & - & C. gloeosporioides \\
\hline $\mathrm{T}$ & Tom-80 & + & - & - & C. acutatum & $\mathrm{M}$ & Man-95 & - & + & - & C. gloeosporioides \\
\hline $\mathrm{T}$ & Tom-90 & + & - & - & C. acutatum & M & Man-97 & - & + & - & C. gloeosporioides \\
\hline $\mathrm{T}$ & Tom-112 & + & - & - & C. acutatum & A & AVO-37-4B & - & + & - & C. gloeosporioides \\
\hline $\mathrm{S}$ & TUT-5954 & + & - & - & C. acutatum & & & & & & \\
\hline
\end{tabular}

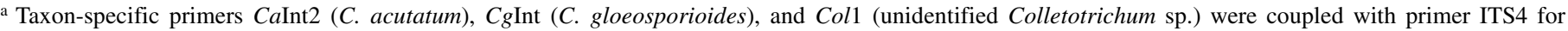
species identification; a positive $(+)$ or negative $(-)$ reaction with fungal DNA of each isolate is designated; $( \pm)$ designates a weak reaction. 
3; Fig. 4). The isolates within this cluster were more distant to the C. gloeosporioides complex but more closely related to C. graminicola, C. dematium (Fig. 4), and other Colletotrichum spp. (data not shown).

Homology values were calculated according to a data matrix calculated from the sequence divergence (data not shown). Sequence analysis based on the ITS2 region indicated respective homology levels of 99.5 and $97.8 \%$ among tamarillo isolates Tom9, Tom-12, and Tom-21 and reference isolates of clusters I and II, belonging to the $C$. acutatum species (14). Respective homologies of the $C$. acutatum tamarillo isolates compared with isolate Tom-6 from tamarillo ranged between 89.0 to $91.2 \%$; with passiflora isolates between 89.8 to $92.1 \%$; and with the mango isolates between 91.0 to $92.1 \%$. Homology between the typical C. gloeosporioides isolates (AVO-37-4B, APL-7, CG-231, Man-53, and Man-69) and those from passiflora (Man-76 and Tom-6) ranged from 94.5 to $95.5 \%$, whereas similarity among the C. gloeosporioides isolates ranged between 98.9 and 100\%. The Pass-35 isolate was associated with an outgroup, clustering with isolates of two Colletotrichum spp., C. fructigenum and C. trichellum (Fig. 4). Homology of Pass-35 with tested tamarillo, passiflora, and mango isolates of $C$. gloeosporioides and $C$. acutatum sequences was between 76.7 and $80.0 \%$, further corroborating results observed with the taxon-specific analysis (Fig. 1).

\section{DISCUSSION}

This study was carried out to identify the species of Colletotrichum causing anthracnose of tamarillo, mango, and passiflora in Colombia, and to evaluate whether cross-infection between these host crops is occurring. Molecular methods were used for characterization of the species responsible for anthracnose of the various crops because morphological descriptors were not reliable for

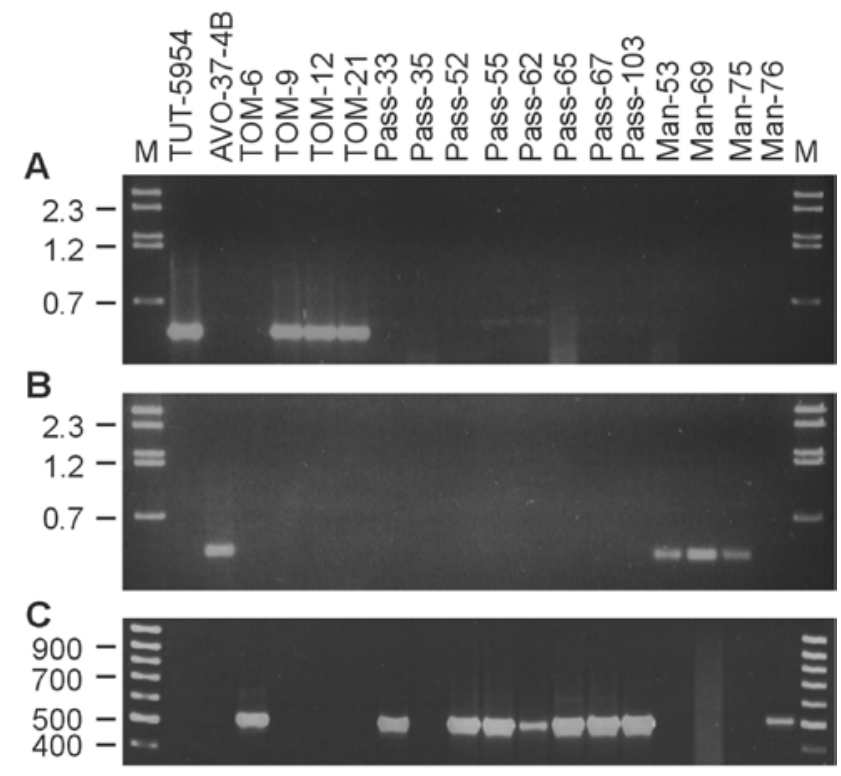

Fig. 1. Taxon-specific identification of A, Colletotrichum acutatum (primer CaInt2 in combination with primer internal transcribed spacer [ITS]4), B, $C$. gloeosporioides (primer $\mathrm{Cg}$ Int in combination with primer ITS4) and $\mathbf{C}$, an unidentified Colletotrichum population (primer Col1 in combination with primer ITS 4) according to amplification products of genomic DNA from $C$. acutatum isolates from strawberry (representative TUT-5954) and tamarillo (representatives Tom-9, Tom-12, and Tom-21); from C. gloeosporioides isolates from avocado (representative AVO 37-4B) and mango (representatives Man-53, Man-69, and Man-75); and from a population of Colletotrichum isolates from tamarillo (Tom-6), passiflora (representatives Pass-33, Pass-52, Pass-55, Pass-62, Pass-65, Pass-67, and Pass-103), and mango (Man-76). An additional unidentified isolate from passiflora (Pass-35) did not react with any of the polymerase chain reaction primers. Lane M: DNA markers with sizes in kilobases. pathogen identification. Genetic diversity of the different populations also was assessed for each host-derived population.

The $C$. acutatum- and $C$. gloeosporioides-specific primers used here have been utilized in numerous studies for identification of Colletotrichum populations affecting various hosts. For example, using this approach, it was confirmed that $C$. acutatum is the causal species of almond anthracnose in California (9), and that two Colletotrichum spp., C. acutatum and C. gloeosporioides, are responsible for anthracnose of citrus in Florida (6). In this study, these primers were reliable for differentiating between the isolates from tamarillo and mango at the species level, but not for isolates from passiflora. Based on the species-specific primer analysis, all tamarillo isolates, except Tom-6, were identified as $C$. acutatum, whereas the mango isolates, other than Man-76, were identified as C. gloeosporioides. Although the passiflora, Man-76, and Tom-6 isolates were identified as $C$. gloeosporioides according to morphological criteria, they did not react with the C. gloeosporioidesspecific primer (Fig. 1B). However, using the Col1 primer, a specific product was obtained, but only from this population (Fig. 1C). These results suggest that this population belongs to an as yet unidentified species of Colletotrichum based on taxon-specific amplification and sequence analysis. It should be noted, however, that two of the three additional isolates clustering with this population (BBA 70539 and AHU 9748) (Table 3; Fig. 4) were identified as Colletotrichum spp.; and, indeed, this cluster does not correspond to typical $C$. gloeosporioides based on ITS sequence. However, a third isolate from citrus (BBA 71334) was classified as C. gloeosporioides. This further demonstrates the incongruence between morphological criteria and molecular methodology for species identification in Colletotrichum.
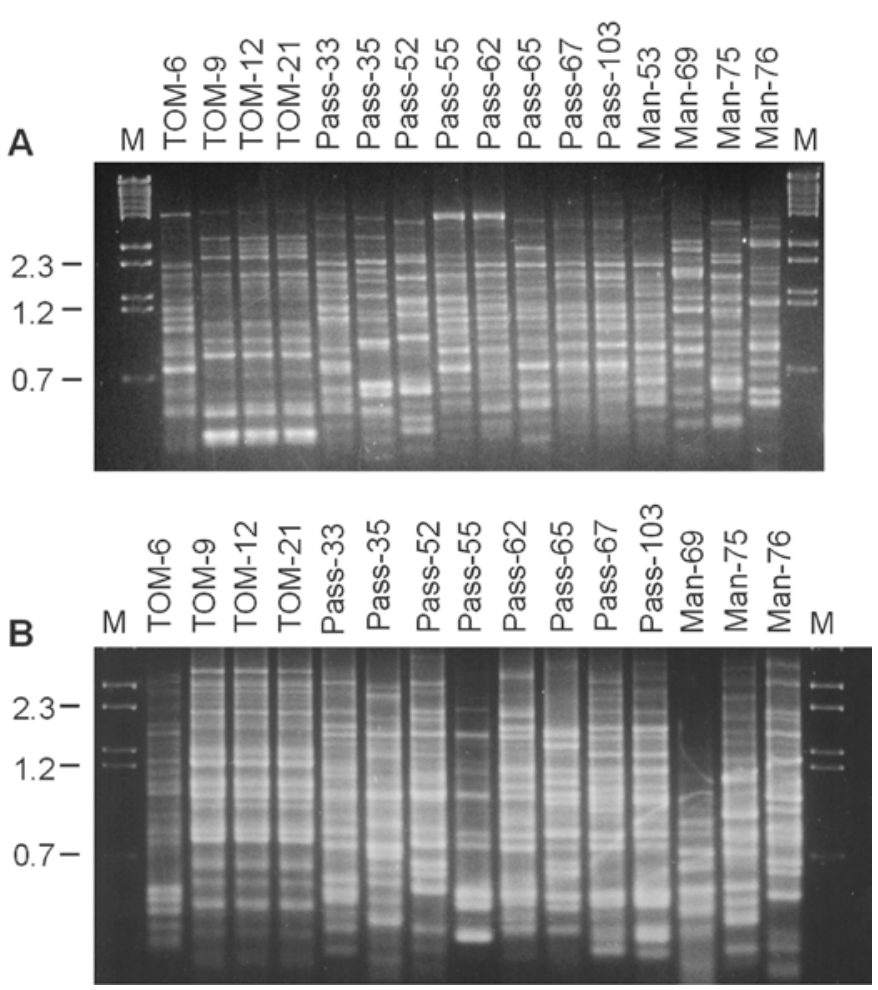

Fig. 2. Band patterns of arbitrarily primed polymerase chain reaction amplified genomic DNA of representative Colletotrichum isolates: C. acutatum isolates from strawberry (representative TUT-5954) and tamarillo (representatives Tom-9, Tom-12, and Tom-21); from C. gloeosporioides isolates from avocado (representative AVO 37-4B) and mango (representatives Man53, Man-69, and Man-75); and from a population of Colletotrichum isolates from tamarillo (Tom-6), passiflora (representatives Pass-33, Pass-52, Pass55, Pass-62, Pass-65, Pass-67, and Pass-103), and mango (Man-76). Primers used: $\mathbf{A},(\mathrm{AGG})_{5}$ and $\mathbf{B},(\mathrm{GACA})_{4}$. Lane $\mathrm{M}$ : DNA markers with sizes in kilobases. 
ITS1-2 sequence analysis is reliable for phylogeny and systematics of Colletotrichum spp. $(1,13,23,28)$ as opposed to other filamentous fungi such as Fusarium spp. (25). Therefore, this approach was applied to a representative set of isolates to verify identification of the Colletotrichum spp. causing anthracnose of tamarillo, mango, and passiflora in various regions of Colombia. In a previous study, based on ITS2 sequence data, four separate clusters or subgroups of $C$. acutatum isolates were identified (14). Subgroup I comprised mainly U.S. isolates from the various fruit; subgroup II comprised mainly anemone, olive, and strawberry isolates; subgroup III was represented by isolate ALM-KSH-10 and C. acutatum strawberry isolate IMI 345026 from Spain; and an anemone isolate NL-12A from the Netherlands represented subgroup number IV. In this study, sequence analysis of the ITS2 region was reliable and consistent, corroborating the taxon-specific analysis regarding the tamarillo isolates, by grouping this population within a new cluster of $C$. acutatum isolates, subgroup V, with $C$. lupini (Fig. 4). The mango isolates clustered within a group of previously defined isolates of $C$. gloeosporioides from various fruit according to specific amplification and sequence analysis (13). However, the $C$. gloeosporioides-specific primer did not react with DNA from the passiflora, Tom-6, and Man-76 isolates (Fig. 1) and ITS2 sequence analysis placed these isolates in a cluster distant from the $C$. gloeosporioides complex, but closer to representatives of $C$. dematium and $C$. graminicola. The Pass-35 isolate also was not identified to species according to the taxon-specific primers, including Col1 (Fig. 1). However, sequence analysis and morphological criteria placed this isolate within genus Colletotrichum, clustering with two isolates of $C$. destructivum and $C$. orbiculare, further indicating the importance of sequence data for identification of species within this genus. Therefore, it appears that a large database of ITS1-2 sequences of Colletotrichum isolates should be generated in order to compile a reliable phylogenetic tree for differentiating between species of this genus.

Genetic diversity of the populations was assessed using apPCR, RAPD-PCR, and A+T-rich DNA analyses. Within the tamarillo $C$. acutatum population, uniformity of banding patterns was observed, indicating clonality. Similar results were reported

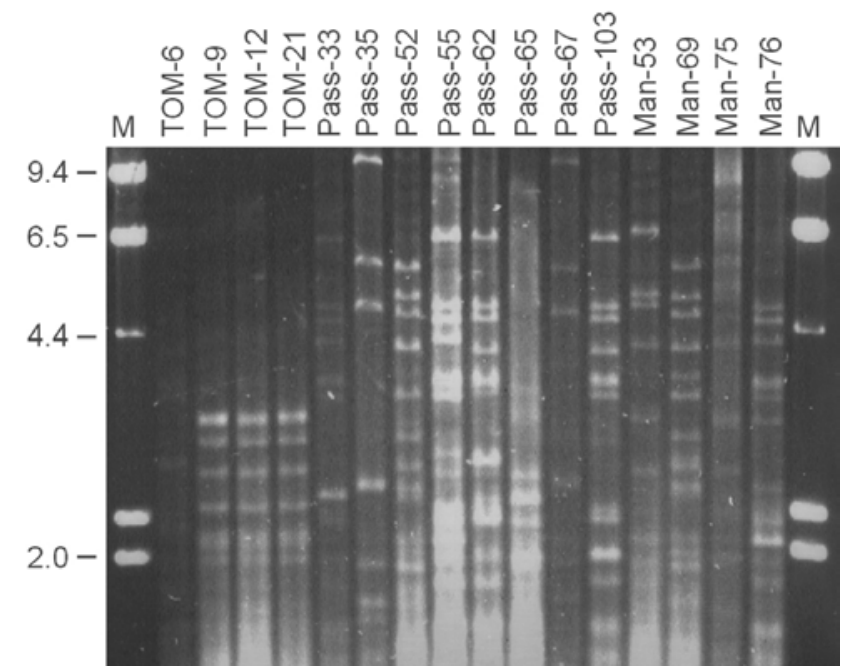

Fig. 3. Band patterns of mitochondrial DNA from Colletotrichum isolates: $C$. acutatum isolates from strawberry (representative TUT-5954) and tamarillo (representatives Tom-9, Tom-12, and Tom-21); from C. gloeosporioides isolates from avocado (representative AVO 37-4B) and mango (representatives Man-53, Man-69, and Man-75); and from a population of Colletotrichum isolates from tamarillo (Tom-6), passiflora (representatives Pass-33, Pass-52, Pass-55, Pass-62, Pass-65, Pass-67, and Pass-103), and mango (Man-76). Isolates were digested with HaeIII for A+T-rich DNA analysis. DNA was electrophoresed until the major $\mathrm{G}+\mathrm{C}$-rich fragments were eluted from the gel. Lane M: DNA markers with sizes in kilobases. for C. acutatum infecting almond (9) and strawberry (12), indcating that minimal variability may be associated with host specificity. On the other hand, genetic diversity of $C$. gloeosporioides has been reported on many occasions $(5,8,11,19)$. Likewise, in this study, the mango $C$. gloeosporioides isolates and those from passiflora were heterogeneous according to the molecular methods employed. Variability was observed within the population of $\mathrm{Col}$ letotrichum isolated from passiflora, which included the tamarillo (Tom-6) and mango (Man-76) isolates. If we assume that this population of isolates belongs to a single species, the genetic complexity and heterogeneity may be explained by the presence of a perfect stage (12). Furthermore, the diversity observed within this subpopulation may be associated with adaptation of these isolates to a nonspecific, broad host range. For example, the Colletotrichum isolates from passiflora originated from various species and cultivars of the host, relieving the pressure for selection within the population. In contrast, variation was not observed among isolates of the tamarillo population, originating from a region where a single cultivar of this host is cultivated, a factor that may promote selection for clonality and homogeneity.

In summary, the molecular methods used for studying the anthracnose pathogens of tamarillo, mango, and passiflora, mainly

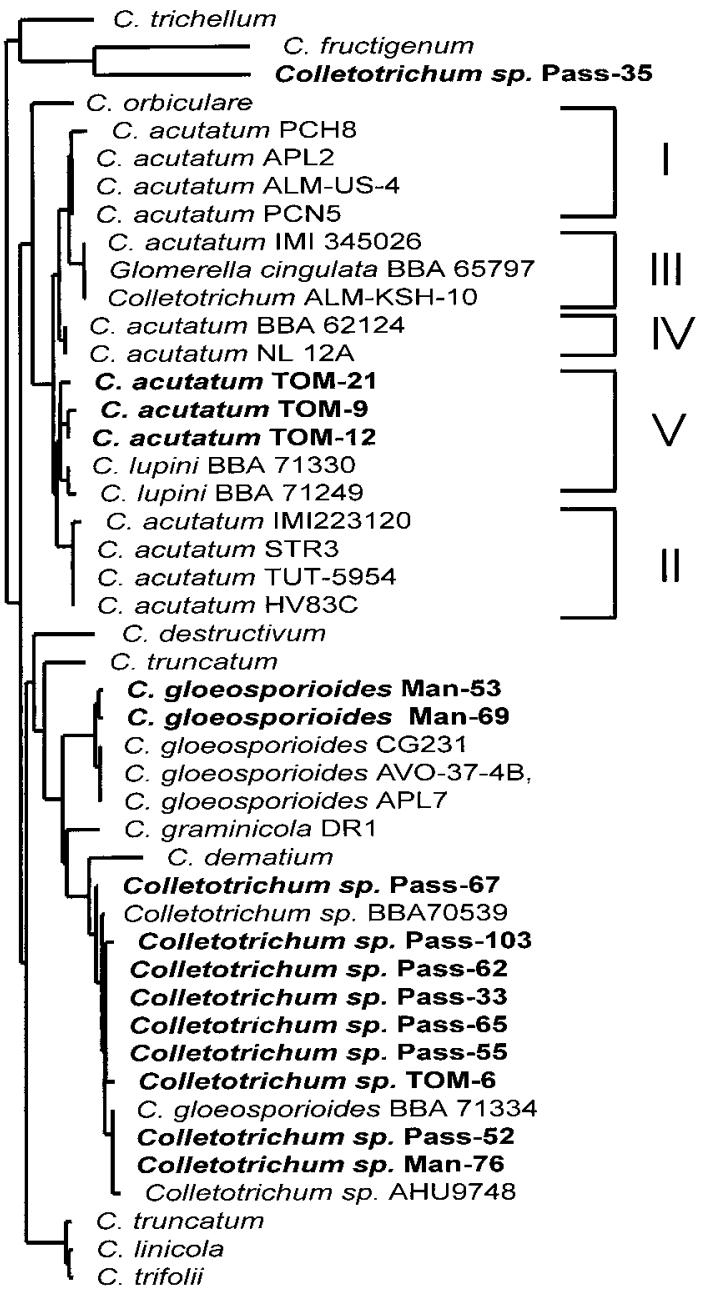

0.1

Fig. 4. Internal transcribed spacer 2-based phylogenetic tree of Colletotrichum isolates and published sequences. The tree was produced using the neighbor-joining algorithm. The order of branching was similar in all tree construction approaches used. Scale bar indicates estimated $10 \%$ sequence divergence. 
from Antioquia, Colombia, identified the tamarillo population as limited to this host and clonal, belonging to $C$. acutatum, and the mango population as $C$. gloeosporioides. Another as yet undefined species of Colletotrichum also was identified, including isolates from passiflora, tamarillo (Tom-6), and mango (Man-76), according to sequence of the ITS region, indicating that this population may not be host specific.

\section{ACKNOWLEDGMENTS}

Contribution from the Agricultural Research Organization, Institute of Plant Protection, Bet Dagan, Israel, No. 511/02. This research was supported by the Volcani Center, Bet Dagan, Israel and Universidad Nacional de Colombia, Sede Medellín. We thank P. F. Cannon of CABI Bioscience, Egham, England for isolate identification; M. L. Corpoica, Colombia for passiflora samples; and P. Tamayo, Corpoica, Colombia for some tamarillo isolates.

\section{LITERATURE CITED}

1. Abang, M. M., Winter, S., Green, K. R., Hoffman, P., Mignouna, H. D., and Wolf, G. A. 2002. Molecular identification of Colletotrichum gloeosporioides causing yam anthracnose in Nigeria. Plant Pathol. 51:63-71.

2. Adaskaveg, J. E., and Hartin, R. J. 1997. Characterization of Colletotrichum acutatum isolates causing anthracnose of almond and peach in California. Phytopathology 87:979-987.

3. Alahakoon, P. W., Brown, A. E., and Sreenivasaprasad, S. 1994. Crossinfection potential of genetic groups of Colletotrichum gloeosporioides on tropical fruits. Physiol. Mol. Plant Pathol. 44:93-103.

4. Aranzazu, L. F., and Rondón, J. G. 1999. Manejo productivo del cultivo del tomate de árbol (Solanum betacea) y de la antracnosis. Boletín Divulgativo 1999. Corpoica-Pronatta. Produmedios Santafé de Bogotá, DC, Colombia.

5. Bernstein, B., Zehr, E. I., Dean, R. A., and Shabi, E. 1995. Characteristics of Colletotrichum from peach, apple, pecan, and other hosts. Plant Dis. 79:478-482.

6. Brown, A. E., Sreenivasaprasad, S., and Timmer, L. W. 1996. Molecular characterization of slow-growing orange and Key lime anthracnose strains of Colletotrichum from citrus as C. acutatum. Phytopathology 86:523-527.

7. Buritica, P. 1995. Impacto de las enfermedades de las plantas en Colombia. Ascolfi Informa. Voumen 21:2-12.

8. Correll, J. C., Rhoads, D. D., and Guerber, J. C. 1994. Genetic and molecular diversity of populations of Glomerella cingulata, Colletotrichum gloeosporioides, and C. acutatum from apple fruit (Abstr.). Page 77 in: 5th Int. Mycol. Congr., Vancouver, Canada.

9. Förster, H., and Adaskaveg, J. E. 1999. Identification of subpopulations of Colletotrichum acutatum and epidemiology of almond anthracnose in California. Phytopathology 89:1056-1065.

10. Freeman, S., and Katan, T. 1997. Identification of Colletotrichum species responsible for anthracnose and root necrosis of strawberry in Israel. Phytopathology 87:516-521.

11. Freeman, S., Katan, T., and Shabi, E. 1996. Characterization of Colletotrichum gloeosporioides isolates from avocado and almond fruits with molecular and pathogenicity tests. Appl. Environ. Microbiol. 62:10141020.

12. Freeman, S., Katan, T., and Shabi, E. 1998. Characterization of Colletotrichum species responsible for anthracnose diseases of various fruits.
Plant Dis. 82:596-605.

13. Freeman, S., Minz, D., Jurkevitch, E., Maymon, M., and Shabi, E. 2000. Molecular analyses of Colletotrichum species from almond and other fruits. Phytopathology 90:608-614.

14. Freeman, S., Minz, D., Maymon, M., and Zveibil, A. 2001. Genetic diversity within Colletotrichum acutatum sensu Simmonds. Phytopathology 91:586-592.

15. Freeman, S., Pham, M., and Rodriguez, R. J. 1993. Molecular genotyping of Colletotrichum species based on arbitrarily primed PCR, A+Trich DNA, and nuclear DNA analyses. Exp. Mycol. 17:309-322.

16. Freeman, S., and Rodriguez, R. J. 1995. Differentiation of Colletotrichum species responsible for anthracnose of strawberry by arbitrarily primed PCR. Mycol. Res. 99:501-504.

17. Freeman, S., and Shabi, E. 1996. Cross-infection of subtropical and temperate fruits by Colletotrichum species from various hosts. Physiol. Mol. Plant Pathol. 49:395-404.

18. Grossman, L. I., and Hudspeth, M. E. S. 1985. Fungal mitochondrial genomes. Pages 65-103 in: Gene Manipulations in Fungi. J. W. Bennet and L. L. Lazure, eds. Academic Press, New York.

19. Guerber, J. C., and Correll, J. C. 1997. The first report of the teleomorph of Colletotrichum acutatum in the United States. Plant Dis. 81:1334.

20. Gupta, M., and Filner, P. 1991. Microsatellites amplify highly polymorphic DNA bands in SPAR of plant DNA. Abstr. 1705 in: Proc. Int. Soc. Plant Mol. Biol., Tucson, AZ.

21. Jeffries, P., Dodd, J. C., Jeger, M. J., and Plumbley, R. A. 1990. The biology and control of Colletotrichum species on tropical fruit crops. Plant Pathol. 39:343-366.

22. Liyanage, H. D., McMillan, R. T., Jr., and Kistler, H. C. 1992. Two genetically distinct populations of Colletotrichum gloeosporioides from citrus. Phytopathology 82:1371-1376.

23. Martín, M. P., and García-Figueres, F. 1999. Colletotrichum acutatum and $C$. gloeosporioides cause anthracnose in olives. Eur. J. Plant Pathol. 105:733-741.

24. Nirenberg, H. I., Feiler, U., and Hagedorn, G. 2002. Description of Colletotrichum lupini comb. nov. in modern terms. Mycologia 94:307320.

25. O’Donnell, K., Cigelnik, E., and Nirenberg, H. I. 1998. Molecular systematics and phylogeography of the Gibberella fujikuroi species complex. Mycologia 90:465-493.

26. Rodriguez, R. J., and Yoder, O. C. 1991. A family of conserved repetitive DNA elements from the fungal plant pathogen Glomerella cingulata (Colletotrichum lindemuthianum). Exp. Mycol. 15:232-242.

27. Sambrook, J., Fritsch, E. F., and Maniatis, T. 1989. Molecular Cloning: A Laboratory Manual. 2nd ed. Cold Spring Harbor Laboratory, Cold Spring Harbor, NY.

28. Sreenivasaprasad, S., Mills, P. R., Meehan, B. M., and Brown, A. E. 1996. Phylogeny and systematics of 18 Colletotrichum species based on ribosomal DNA spacer sequences. Genome 39:499-512.

29. Strunk, O., Ludwig, W., Gross, O., Reichel, B., Stuckmann, N., May, M., Nonhoff, B., Lenke, M., Ginhart, T., Vilbig, A., and Westran, R. 1998. ARB - A software environment for sequence data. Technische Universität München, Munich, Germany.

30. Weising, K., Weigand, F., Driesel, A. J., Kahl, A. J., Zischer, H., and Epplen, J. T. 1989. Polymorphic simple GATA/GACA repeats in plant genomes. (Abstr.) Nucleic Acids Res. 17:10128.

31. White, T. J., Bruns, T., Lee, S., and Taylor, J. 1990. Amplification and direct sequencing of fungal ribosomal RNA genes for phylogenetics. Pages 315-322 in: PCR Protocols: A Guide to Methods and Applications. M. A. Innis, D. H. Gelfand, and J. J. Sninsky, eds. Academic Press, San Diego, CA. 